\title{
A new aortoventriculoplasty for prosthetic aortic valve replacement
}

Ulrik Hvass, MD

Franck Baron, MD

A. Elsebaey, MD

From the Hôpital Bichat AP-HP, Paris, France.

Received for publication Oct 24, 2002; revisions requested Nov 12, 2002; revisions received Nov 20, 2002; accepted for publication Dec 2, 2002.

Address for reprints: Dr U. Hvass, AP-HP Hôpital Bichat, 46 rue Henri Huchard, Paris 75018, France (E-mail: Ulrik.Hvass@bch. ap-hop-paris.fr).

J Thorac Cardiovasc Surg 2003;126:818-20

Copyright $\odot 2003$ by The American Association for Thoracic Surgery

$0022-5223 / 2003 \$ 30.00+0$

doi:10.1016/S0022-5223(03)00090-4
Background: Konno aortoventriculoplasty demands a complex double patch reconstruction of left and right ventricular outflow tracts and is subjected to a risk of permanent heart block. A modified technique was used to overcome these difficulties.

Patient and Methods: A 42-year-old woman with congenital aortic stenosis, a diminutive aortic annulus, and severe subaortic muscular obstruction had undergone aortic valve commissurotomy 24 years ago. At reoperation, a 19-mm St Jude Medical sizer had a very tight fit after removal of the calcified aortic valve. To enlarge the aortic annulus and septum, the pulmonary artery valve was first partly separated from the right ventricle, exposing the interventricular septum. The aortic wall, annulus, and septum were then split along the intercoronary commissure, a location that clears the aortoventriculoplasty from the path of the major conducting tissue. Once the septum was reconstructed with a Dacron patch, the enlarged orifice accepted a St Jude Medical Flex 23. The mobilized pulmonary artery valve was then sutured back to its original position, only changed by the width of the septal Dacron patch.

Result: Discharge echocardiogram recorded a $7 \mathrm{~mm} \mathrm{Hg}$ mean transprosthetic gradient with a normally functioning pulmonary valve. The electrocardiogram showed permanent sinus rhythm.

Conclusions: The described aortoventriculoplasty has several advantages, including: a simple exposure obtained by partly separating the pulmonary artery valve from the right ventricle; clear septal opening landmarks that avoid the conducting tissue; easy reconstruction with a single septal patch; and an anatomically restored right ventricular outflow tract.

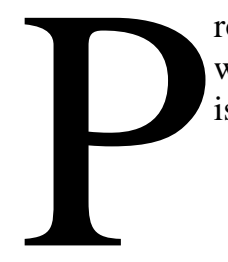

rosthetic valve replacement in congenital aortic stenosis associated with a diminutive aortic valve ring and subaortic muscular obstruction is best addressed by aortoventriculoplasty.

\section{Patient and Methods}

The patient was a 42-year-old woman with congenital aortic stenosis who had undergone aortic valve commissurotomy 24 years previously. Preoperative echocardiogram showed a calcified aortic valve with a transvalvular mean gradient of 60 $\mathrm{mm} \mathrm{Hg}$ and considerable left ventricular hypertrophy with a septal thickness of 22 $\mathrm{mm}$. The diameter of the aortic annulus as seen on echocardiogram was estimated to be around 21 to $23 \mathrm{~mm}$. She also presented with a 55-mm aneurysm of the ascending aorta starting above the sinotubular junction. The initial demand was aortic valve replacement with a mechanical device. 


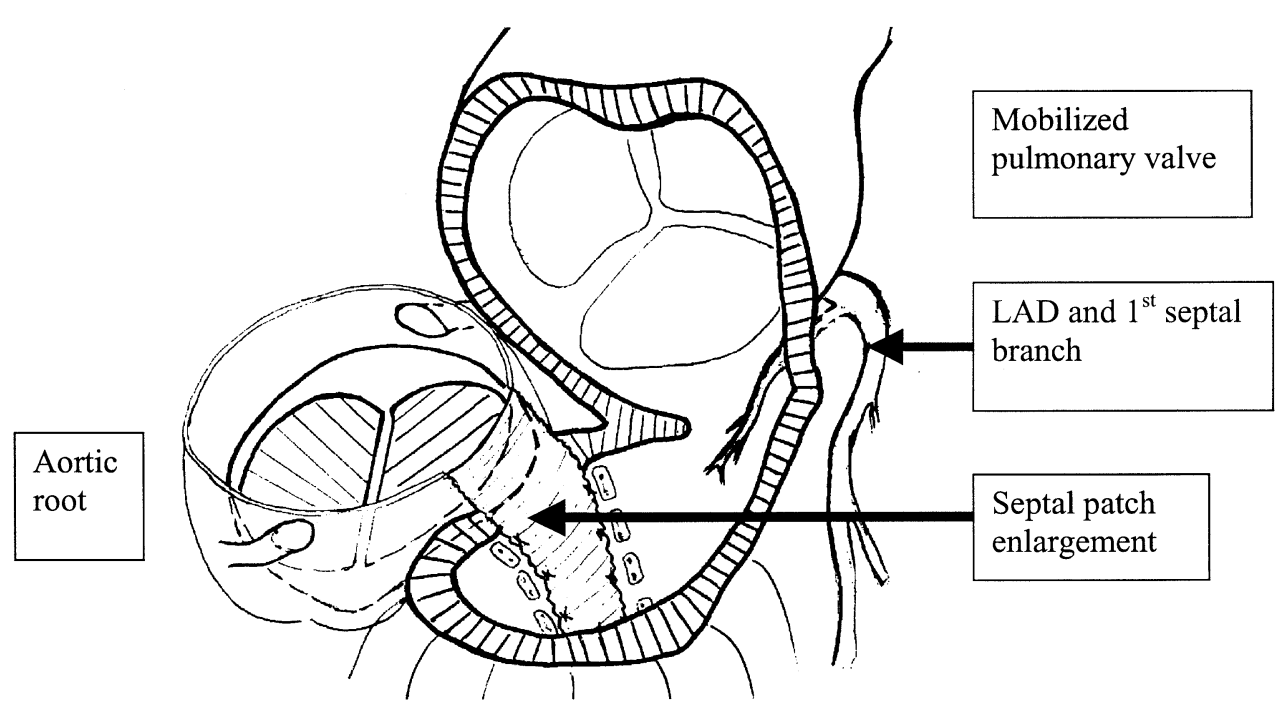

Figure 1. Aortoventriculoplasty.

At operation the aorta was transected above the commissures, the localized aneurysm resected, and the calcified native valve removed. Septal hypertrophy was partly obstructing the outflow tract. The size of the aortic annulus was evaluated with a St Jude Medical obturator: the 19-mm measurer had a very tight fit. To avoid serious mismatch and the effects of significant residual subvalvular obstruction, a more extensive operation was needed than simple valve replacement.

Following guidelines of autograft harvesting, we then proceeded by partly separating the pulmonary artery valve from the right ventricle, beginning with a short incision in the anterior right ventricular wall below the valve sinuses. (Viewing the sinuses from within the pulmonary artery trunk opened intentionally for that purpose might facilitate locating an adequate site and avoid any risk of harm to the valve leaflets.) The anterior incision is continued laterally, 3 to $5 \mathrm{~mm}$ away from the pulmonary valve leaflets. Toward the left side, sharp dissection is stopped before reaching the area of the left anterior descending coronary artery. Toward the right side, the incision is carried on around the pulmonary valve until approaching the posterior area through which passes the first septal branch, avoiding the risk of arterial injury (Figure 1). This maneuver uncovers the interventricular septum where it is aligned with the intercoronary commissure. The remnant of the aortic wall was opened at that level; the incision was continued by transecting the aortic annulus and finally extending the opening by $3 \mathrm{~cm}$ into the interventricular septum. A Dacron patch was tailored to fit the enlargement, approximately $2 \mathrm{~cm}$ by $4 \mathrm{~cm}$, and was positioned on the right side of the septal opening, increasing the annular circumference of $1.5 \mathrm{~cm}$. A St Jude Medical Flex 23-mm valve was then inserted on the patient's annulus and its Dacron extension. The ascending aorta was replaced by a 26-mm diameter Dacron tube. The mobilized pulmonary valve was finally repositioned back to its initial location, only slightly changed by the Dacron septal enlargement. No prosthetic reconstruction was necessary here; the right ventricular outflow tract was flexible enough to absorb the small difference in circumference.

At discharge, the electrocardiogram showed sinus rhythm. Left ventricular function was normal with a pulsed Doppler mean transprosthetic gradient of $7 \mathrm{~mm} \mathrm{Hg}$. The right ventricle was normal with no regurgitation on the pulmonary valve.

\section{Discussion}

In the presence of a small aortic annulus and diffuse subaortic muscular obstruction, left ventricular outflow tract enlargement is best addressed by aortoventriculoplasty.

When prosthetic valves are expected for aortic valve replacement, the Konno-Rastan operation was the only efficient option to relieve the obstructed left ventricular outflow tract. ${ }^{1,2}$ This is, however, a complex operation needing double ventricular reconstruction, and one where the septal opening, using the right coronary artery ostia as a landmark, can more easily harm the conducting tissue.

Relief of complex left ventricular outflow tract obstruction can also be efficiently accomplished with pulmonary autografts. ${ }^{3-5}$ The septal opening, made through the intercoronary commissure, is in a different location compared with the Konno operation. The intercoronary commissure landmark is out of reach of the atrioventricular conducting tissue.

Combining the advantages of septal patch enlargement located at the intercoronary commissure followed by mechanical valve replacement suppresses the technical difficulties of the Konno operation. 


\section{Conclusion}

The present technique offers the advantages of a simple exposure obtained by partly separating the pulmonary artery valve from the right ventricle, clear septal landmarks that avoid the major conducting tissue, and easy reconstruction with a single septal patch and an anatomically restored right ventricular outflow tract.

\section{References}

1. Konno S, Imai Y, Lida Y, Nakajima M, Tatsuno K. A new method for prosthetic valve replacement in congenital aortic stenosis associated with hypoplasia of the aortic valve ring. $J$ Thorac Cardiovasc Surg. 1975;70:909-17.

2. Rastan H, Koncz J. Aortoventriculoplasty: a new technique for the treatment of left ventricular outflow obstruction. $J$ Thorac Cardiovasc Surg. 1976;71:920-7.

3. Matsuki O, Okita Y, Almeida RS, et al. Two decades experience with aortic valve replacement with pulmonary autograft. $J$ Thorac Cardiovasc Surg. 1988;95:705-11.

4. Daenen W, Gewillig M. Extended aortic root replacement with pulmonary autografts. Eur J Cardiothorac Surg. 1993;7:42-6.

5. Hvass U, Chatel D, Caliani J, Pansard Y. Relief of complex left ventricular outflow tract obstruction with pulmonary autografts. J Thorac Cardiovasc Surg. 1995;109:1019. 